\title{
Front Matter: Volume 10284
}

, "Front Matter: Volume 10284," Proc. SPIE 10284, Optoelectronic Interconnects and Packaging: A Critical Review, 1028401 (30 January 1996); doi: $10.1117 / 12.2285114$

SPIE. Event: Photonics West '96, 1996, San Jose, CA, United States 


\section{Contents}

ix Conference Committee

xi Preface

\section{FREE-SPACE OPTOELECTRONIC INTERCONNECTS}

3 Vertical-cavity surface-emitting lasers for free-space interconnects

L. A. Coldren, B. J. Thibeault, Univ. of California/Santa Barbara

35 Low-power approaches for parallel free-space photonic interconnects

R. F. Carson, M. L. Lovejoy, K. L. Lear, M. E. Warren, P. K. Seigal, D. C. Craft, S. P. Kilcoyne, G. A. Patrizi, O. Blum, Sandia National Labs.

64 Board-to-board free-space optical interconnects of bus architecture J. Ma, V. H. Ozguz, S. H. Lee, Univ. of California/San Diego

68 Smart multichip module communications using free-space optical interconnects

D. S. McCallum, P. S. Guilfoyle, OptiComp Corp.

88 Multilevel phase holograms for free-space optical interconnects: design and analysis

A. F. Gmitro, C. L. Coleman, Optical Sciences Ctr./Univ. of Arizona

106 Integrated optoelectronic interconnects using liquid-crystal-on-silicon VLSI J.-J. P. Drolet, G. Barbastathis, D. Psaltis, California Institute of Technology

\section{INTERCONNECT ARCHITECTURES}

135 VCSEL array-based optoelectronic crossbar interconnect

Y. Li, T. Wang, R. A. Linke, NEC Research Institute

156 Optoelectronic parallel computing system with reconfigurable optical interconnection

M. Ishikawa, Univ. of Tokyo (Japan)

176 Network-related performance issues and techniques for MPPs

S. L. Johnsson, Univ. of Houston and Harvard Univ.

210 Bit-parallel wavelength links for high-performance computer networks

L. A. Bergman, Jet Propulsion Lab.; A. J. Mendez, Mendez R\&D Associates;

L. S. Lome, Ballistic Missile Defense Organization

Optoelectronic Interconnects and Packaging: A Critical Review, edited by Ray T. Chen, Peter S. Guilfoyle, Proc. of SPIE Vol. 10284 (Vol. CR62), 1028401 - (c) (1996) 2017 SPIE CCC code: $0277-786 \mathrm{X} / 17 / \$ 18 \cdot$ doi: $10.1117 / 12.2285114$ 


\section{HIGH-SPEED TRANSCEIVERS FOR OPTOELECTRONIC INTERCONNECTS}

229 VCSEL-based optical interconnections at interbox distances and shorter J. L. Jewell, Picolight Inc.

244 Design and fabrication of low-power 1-Gb/s OEIC receivers

W. Chang, D. D. Airola, M. Feng, Univ. of Illinois/Urbana-Champaign

267 Clock recovery for high-speed optical communication

K. D. Pedrotti, Rockwell International Corp.

\section{BACKPLANE OPTOELECTRONIC INTER CONNECTS}

299 Performance-optimized optical bidirectional backplane bus for multiprocessor systems

R. T. Chen, C. Zhao, T. Oh, Univ. of Texas/Austin

318 Intracomputer optical interconnects: progress and challenges

J. P. Bristow, Honeywell Technology Ctr.

\section{INTRA- AND INTER-MCM OPTOELECTRONIC INTERCONNECTS}

329 Optical interconnection using polyimide waveguide for multichip module M. Koyanagi, Tohoku Univ. (Japan)

343 Implementation of optical interconnects in the GigaRing supercomputer channel

R. W. Wickman, Cray Research Inc.

366 Optoelectronic interconnects for three-dimensional wafer stacks

D. E. Ludwig, J. C. Carson, Irvine Sensors Corp.; L. S. Lome, Ballistic Missile Defense Organization

\section{OPTOELECTRONIC PACKAGING}

393 POLO: a gigabyte/s parallel optical link

K. H. Hahn, D. W. Dolfi, Hewlett-Packard Labs.

405 Polymer optical interconnect technology (POINT): optoelectronic packaging and interconnect for board and backplane applications

Y. S. Liu, R. J. Wojnarowski, W. A. Hennessy, GE Corporate Research and

Development Ctr.; J. P. Bristow, Y. Liu, A. Peczalski, Honeywell Technology

Ctr.; J. R. Rowlette, A. Plotts, J. D. Stack, AMP, Inc.; J. T. Yardley, L. Eldada,

AlliedSignal Inc.; R. M. Osgood, R. Scarmozzino, Columbia Univ.; S. H. Lee, V.

H. Ozguz, Univ. of California/San Diego 
415 Fabrication and performance of optical interconnect analog phase holograms made by electron-beam lithography

P. D. Maker, D. W. Wilson, R. E. Muller, Jet Propulsion Lab.

431 Packaging and applications of active polymer optical switching arrays

R. S. Lytel, F. Lipscomb, Akzo Nobel Electronic Products Inc.

442 Potential of LIGA technology for optoelectronic interconnects

W. Bacher, P. Bley, H. O. Moser, Forschungszent rum Karlsruhe GmbH (FRG) 
Proc. of SPIE Vol. 10284 1028401-4

Downloaded From: https://www.spiedigitallibrary.org/conference-proceedings-of-spie on 26 Apr 2023 Terms of Use: https://www.spiedigitallibrary.org/terms-of-use 


\title{
Conference Committee
}

\author{
Conference Chairs
}

Ray T. Chen, University of Texas/Austin

Peter S. Guilfoyle, OptiComp Corporation

\section{Session Chairs}

1 Free-Space Optoelectronic Interconnects

Peter S. Guilfoyle, OptiComp Corporation

2 Interconnect Architectures

Julian P. Bristow, Honeywell Inc.

3 High-Speed Transceivers for Optoelectronic Interconnects

Yao Li, NEC Research Institute

$4 \quad$ Backplane Optoelectronic Interconnects

Randy W. Wickman, Cray Research Inc.

5 Intra- and Inter-MCM Optoelectronic Interconnects

Yung S. Liu, GE Corporate Research and Development Center

6 Optoelectronic Packaging

Ray T. Chen, University of Texas/Austin 
Proc. of SPIE Vol. 10284 1028401-6

Downloaded From: https://www.spiedigitallibrary.org/conference-proceedings-of-spie on 26 Apr 2023 Terms of Use: https://www.spiedigitallibrary.org/terms-of-use 


\section{Preface}

Optoelectronic interconnects and packaging are becoming increasingly important due to the requirement of high-speed, large-capacity transmission of information. Such a demand in many scenarios such as machine-to-machine and module-to-module interconnects can only be realized by employing optoelectronic technology.

In this critical review, we have invited 26 internationally known experts in this field to address such critical technical issues as vertical cavity surface emitting lasers, photodetectors, holograms and smart pixel arrays for both guided wave and free-space optoelectronic interconnects. Architecture-related subjects are also delineated to provide a global picture of future development. Several system demonstrations, including $500-\mathrm{MHz}$ optical clock signal distribution for Cray Research's T-90 machine, ARPA-sponsored POINT and POLO programs, and the most recent developments on optoelectronic packaging are also detailed in this book.

We expect the engineers, scientists, and students in this field to find this book useful for their research.

Ray T. Chen

Peter S. Guilfoyle 